\title{
WANITA: MENJADI ISTRI DAN PANGGILAN INDUSTRI
}

\author{
Lutfiyah \\ IAIN Walisongo Semarang \\ email: lutfiyahmsi@yahoo.co.id
}

\begin{abstract}
Abstrak
Dalam hubungan perkawinan suami dan istri adalah satu kesatuan dalam keluarga. Ada istilah ayah kepala keluarga, ibu kepala rumah tangga. Ini merupakan simbul baku dari sebuah pepatah yang sampai sekarang sulit untuk dirubah karena sudah terstruktur meskipun sebenarnya keadaan dalam keluarga bisa mengalami perpindahan posisi. Kesadaran dan penguasaan terhadap isu gender dan kesamaan gender ini tidak menyentuh masyarakat pedesaan. Takrif gender tidak mereka pahami apalagi diketahui. Bekerja untuk memenuhi kebutuhan keluarga bukan masalah yang perlu dirisaukan, sehingga jika ada pekerjaan yang mereka bisa lakukan dan berhasil guna maka akan mereka laksanakan dengan senang hati. Jika ada pekerjaan di sekitar tempat tinggal yang bisa mereka lakukan, maka akan mereka lakukan. Misalnya usaha industri di dekan rumah seperti yang dilakukan oleh ibu rumah tangga di Desa Jambearum. Mereka tidak meninggalkan rumah terlalu jauh, bisa mengawasi ank-anak dan bahagia ketika menerima hasil keringatnya.
\end{abstract}

Kata Kunci: gender, industri, ibu rumah tangga

\section{A. Pendahuluan}

Semua manusia baik laki-laki dan perempuan sama dimata hukum. Setiap warga negara memiliki hak yang sama untuk mendapatkan perlakuan yang adil. Wacana ini bukan untuk menggugat terhadap konstruksi biologis (kodrat) tapi lebih pada konstruksi sosiologis (gender). Ideologi gender yang telah mengakar pada orang perorang biasanya akan mewujud dalam sistem dan struktur sosial masyarakat serta membias pada kebijakan baik dalam keluarga, masyarakat atau pemerintahan. Gender keberadaannya 
sering membawa kebingungan dan kejengahan bagi sebagian orang. Manis tidak pahitpun tidak. Secara mendasar gender berbeda dengan jenis kelamin biologis. Jenis kelamin biologis adalah pemberian. Laki-laki atau perempuan. Tetapi jalan yang menjadikan maskulin atau feminin adalah gabungan blok-blok bangunan biologis dasar dan interpretasi oleh kultur. ${ }^{1}$

Ketidakadilan gender tidak dirasakan oleh semua orang. Perasaan ketidak adilan hanya dirasakan oleh orang yang memahami gender, namun bagi yang tidak mengetahui apa dan bagaimana gender tidak ada perubahan yang signifikan bagi kehidupan mereka sehari hari. Contohnya masyarakat desa yang asik dengan kesibukan sehari hari mulai dari bangun tidur sampai tidur lagi. Mereka mengerjakannnya dengan senang, bahagia bahkan untuk bekerja paruh waktu atau bekerja di sekitar rumah akan mereka jalankan dengan tertawa. Lalu untuk siapa gaung feminisme dan diskursus gender ini?

\section{B. Manusia dan "Kodrat"}

Sejak manusia dilahirkan mulai dari bayi sampai usia tua selalu mempelajari dan mempraktikan cara-cara khusus yang telah ditentukan oleh masyarakat untuk menjadi laki-laki atau perempuan, maka gender adalah seperangkat kostum yang diperlihatkan kepada orang lain bahwa orang tersebut feminin atau maskulin.

Untuk memahami konsep gender, harus dibedakan kata gender dan kata seks (jenis kelamin). Jenis kelamin adalah pensifatan dua jenis kelamin manusia yang ditentukan secara biologis yang melekat pada jenis tertentu misalnya laki-laki adalah manusia yang memiliki penis, jekala (kala menjing) dan memproduksi sperma. Sedangkan perempuan memiliki alat reproduksi seperti rahim dan saluran untuk melahirkan, memproduksi telur, memiliki vagina dan alat menyusui, secara biologis alat-alat tersebut tidak bisa dipertukarkan dan secara permanen tidak berubah dan merupakan ketentuan biologis dan sering dikatakan sebagai kodrat atau ketentuan Tuhan.

${ }^{1}$ Julia Cleves Mosse, Gender dan Pembangunan, terj: Hartian Silawatim, (Yogyakarta: Pustaka Pelajar, 2002), hlm. 2. 
Sementara konsep gender menurut Mansour Faqih adalah sifat yang melekat pada laki-laki dan perempuan yang dikonstruksi secara sosial maupun kultural. ${ }^{2}$ Sifat ini dapat dipertukarkan. Secara lengkap Mansour Faqih, ${ }^{3}$ menyebutkan 5 fenomena ketidak adilan gender, yaitu: a) marginalisasi perempuan, baik di rumah tangga atau pekerjaan yang berakibat pada pemiskinan perempuan, b) sub ordinasi perempuan karena anggapan perempuan irasional, dan emosional. c) stereotip yang merugikan, misalnya perempuan bersolek dalam rangka memancing lawan jenis, d) perempuan dianggap lemah, sehingga laki-laki dengan leluasa melakukan kekerasan terhadap perempuan, e) pembagian kerja secara seksual yang merugikan kaum perempuan, misalnya perempuan cocok dalam urusan domestik, oleh karena itu tidak pantas melakukan pekerjaan publik seperti laki-laki, akibatnya perempuan terkurung dalam ruang dan wawasan sempit. konsep ketidak adilan ini menurut para feminis akibat dari kesalah pahaman terhadap konsep gender yang disamakan dengan konsep seks, sekalipun dari konsep kebahasaan kata gender dan seks mempunyai arti yang sama yaitu jenis kelamin. ${ }^{4}$

Gender sebagai konsepsi tidak tepat untuk membahas jenis kelamin. Jenis kelamin mempunyai pengertian untuk menunjukkan tanda-tanda yang tetap dari seseorang. Gender sebagai konsep mengacu pada pengertian bahwa lahirnya sebagai laki-laki atau perempuan keberadaanya berbeda dalam waktu, tempat, kultur bangsa maupun peradaban. Gender adalah interpretasi mental dan kultural terhadap perbedaan kelamin dalam hubungan antar lakilaki dan perempuan. Gender biasanya dipergunakan untuk menunjukkan pembagian kerja yang dianggap tepat bagi laki-laki dan perempuan. ${ }^{5}$

Salah satu hal yang menarik dari gender adalah peran-peran itu berubah seiring waktu dan berbeda antara satu kultur dengan kultur yang lainnya.

${ }^{2}$ Mansour Faqih, Analisis Gender dan Transformasi Sosial, (Yogyakarta: Pustaka Pelajar, 2001), hlm. 7-8.

${ }^{3}$ Mansour Faqih, Menggeser Konsepsi Gender dan Transformasi Sosial, (Yogyakarta: Pustaka Pelajar, 1996), hlm. 11-12.

${ }^{4}$ Echols, John, Hasan Shadzily, Kamus Inggris Indonesia, (Jakarta: Gramedia Pustaka Utama, 1993), hlm. 265, 517.

${ }^{5}$ Syamsiah Ahmad, “Kajian terhadap Masalah-Masalah Wanita”, Makalah, (Jakarta: UI 1990), hlm. 11. 
Peran itu juga amat dipengaruhi oleh kelas sosial dan latar belakang etnis. Dengan kata lain perbedaan gender ini bisa berubah dari waktu ke waktu dan dari kelas ke kelas. Sedangkan perbedaan biologis (sex) bersifat tetap tidak berubah. Di Inggris abad ke-19 ada anggapan bahwa kaum perempuan tidak pantas untuk bekerja di luar rumah guna mendapatkan upah. Tetapi anggapan ini hanya berlaku bagi perempuan kelas menengah ke atas. Kaum perempuan kelas bawah diharapkan bekerja sebagai pembantu bagi perempuan yang tidak dilahirkan untuk bekerja sendiri. Kini keadaan serupa juga terdapat dibeberapa bagian negara berkembang.

Di Indonesia dengan kulturnya yang bercorak patriarki secara sadar atau tidak telah mengkronstruksi perbedaan gender yang cenderung menguntungkan laki-laki dan memposisikan perempuan sebagai sub ordinat. ${ }^{6}$ Perbedaan gender seperti di atas sebenarnya tidak perlu digugat dan dipersoalkan sepanjang perbedaan tersebut tidak menimbulkan dampak yang negatif, dengan kata lain perbedaan gender tidak menjadi masalah selama tidak melahirkan ketidak adilan gender. Namun dalam kenyataannyanya perbedaan tersebut telah melahirkan hubungan dan peran gender yang tidak berkeadilan.

Istilah persamaan (equality) sudah sering digunakan dan dieksploitasi dalam setiap gagasan yang berbau murni atau bermotif tertentu. Ada tiga persamaan yang terkenal telah ditemukan untuk menegaskan persamaan mutlak bagi umat manusia, yaitu manusia adalah sama, manusia punya hak untuk diperlakukan secara sama dan manusia diciptakan secara sederajad. Tetapi kesulitanya adalah mendefinisikan ciri-ciri penting bahwa semua manusia mempunyai tingkat yang sama persis sehingga apapun perbedaan lainnya kesederajadan mereka dibenarkan. Kesederajadan ini kemudian akan menjadikan manusia sama. Al-Qur'an secara pasti telah mengakui persamaan manusia, kemampuannnya untuk mengetahui dan mentransmisikan pengetahuannya kepada yang lain.

\section{Wanita dan Rumah Tangga}

Keluarga merupakan pondasi dasar penyebaran Islam. Dari keluarga muncul para pemimpin dan peran terbesar dalam hal tersebut adalah kaum

${ }^{6}$ Mansour Faqih, Menggeser Konsepsi Gender..., hlm. 14. 
wanita. Ketika seorang laki-laki merasa kesulitan, maka sang istri yang bisa membantunya. Ketika seorang laki-laki mengalami kegundahan, istri yang dapat menenangkannya. Dan ketika laki-laki mengalami keterpurukan, istri yang dapat menyemangatinya. Mengenai hal ini, contoh ada pada Khadijah radhiyallahu 'anha dalam mendampingi Rasulullah di masa awal kenabiannya. Ketika Rasulullah merasa ketakutan terhadap wahyu yang diberikan kepadanya, dan merasa kesulitan, lantas apa yang dikatakan Khadijah kepadanya?

"Demi Allah, Allah tidak akan menghinakanmu selama-lamanya. Karena sungguh engkau suka menyambung silaturahmi, menanggung kebutuhan orang yang lemah, menutup kebutuhan orang yang tidak punya, menjamu dan memuliakan tamu dan engkau menolong setiap upaya menegakkan kebenaran." (HR. Muttafaqun 'alaih)

Inilah peran yang bisa dilakukan bagi seorang wanita. Menjadi seorang pemimpin bukanlah hal yang perlu dilakukan wanita, akan tetapi menjadi pendamping seorang pemimpin (pemimpin rumah tangga atau lainnya) yang dapat membantu, mengarahkan dan menenangkan adalah hal yang sangat mulia jika di dalamnya berisi ketaatan kepada Allah Ta'ala. Tidak ada kemulian terbesar yang diberikan Allah bagi seorang wanita, melainkan perannya menjadi seorang Ibu sebagaimana yang pernah diceritakan oleh Rasulullah. Rasulullah bersabda ketika ditanya oleh seseorang:"Wahai Rasulullah, siapakah orang yang paling berhak untuk kuperlakukan dengan baik?" Beliau berkata, "Ibumu." Laki-laki itu kembali bertanya, "Kemudian siapa?", tanya laki-laki itu. "Ibumu". Laki-laki itu bertanya lagi, "Kemudian siapa?", tanya laki-laki itu. "Ibumu", "Kemudian siapa?" tanyanya lagi. "Kemudian ayahmu", jawab beliau." 7

Di dalam rumah, wanita mempunyai banyak waktu untuk anak-anak? Siapakah yang lebih mempunyai pengaruh terhadap anak-anak? Siapakah yang lebih dekat kepada anak-anak? Tidak lain adalah ibu-ibu mereka. Seorang ibu merupakan seseorang yang senantiasa diharapkan kehadirannya bagi anak-anaknya. Seorang ibu dapat menjadikan anak-anaknya menjadi

${ }^{7}$ HR. Al-Bukhari no. 5971 dan Muslim no. 6447. 
orang yang baik sebagaimana seorang ibu bisa menjadikan anaknya menjadi orang yang jahat. Baik buruknya seorang anak, dapat dipengaruhi oleh baik atau tidaknya seorang ibu yang menjadi panutan anak-anaknya.

Para wanita sadar akan pentingnya dan sibuknya kehidupan di keluarga, ternyata tidak menyurutkan mereka untuk mempunyai kegiatan yang" hasil guna". Kegiatan ini banyak dilakukan oleh masyarakat desa yang merasa hanya membuang waktu percuma kalau hanya harus termangu-mangu setelah mereka menyelesaikan pekerjaan rumah tangga. Hasilnya mereka tidak menelantarkan anak, suami dan kegiatan rumah tangga bahkan memperoleh penghasilan yang lumayan.

\section{Wanita dan Industri}

Wanita mempunyai kelebihan yang unik disbanding dengan laki-laki, seperti etos kerja tinggi, ulet, sabar dan teliti. Keterlibatan wanita dalam ekonomi negara sejak zaman dulu tidak diragukan lagi. Wanita yang hidup didaerah persawahan, mereka akan pergi ke sawah, jika berada di daerah yang ramai nuansa perdagangan, maka wanita yang memenuhi pasar sebagai pedagang. jika dekat dengan kawasan industri, maka wanita paling banyak menjadi karyawan.

Munculnya upaya peningkatkan kesejahteraan masyarakat perdesaan disebabkan oleh: 1) masih kurang berkembang dan terbatasnya akses masyarakat perdesaan pada sumber daya produktif, lahan, permodalan, infrastruktur, dan teknologi dan pelayanan publik/pasar, 2) masih terbatasnya pelayanan prasarana dan sarana permukiman perdesaan, 3) masih terbatasnya kapasitas kelembagaan pemerintahan di tingkat lokal dan kelembagaan sosial ekonomi, 4) masih kurangnya keterkaitan antara kegiatan ekonomi perkotaan dan perdesaan yang mengakibatkan makin meningkatnya kesenjangan ekonomi dan kesenjangan pelayanan infrastruktur antar wilayah.

Ada beberapa penyebab wanita ingin bekerja yaitu: 1) untuk meningkatkan kesejahteraan ekonomi ataupun untuk memenuhi kebutuhan sekolah anak-anaknya, 2) keinginan untuk memiliki teman yang lebih banyak, 3) mengejar status, 4) senang dengan pekerjaan. 
Di dalam benak masyarakat berkembang suatu pemikiran bahwa bekerja menjadi seorang buruh lebih sejahtera hidupnya jika dibandingkan dengan bekerja menjadi seorang petani. Padahal fakta sebenarnya adalah ketika seseorang bekerja menjadi seorang buruh ia akan mendapatkan gaji yang melebihi UMR (Upah Minimum Regional) jika mau bekerja melebihi dari jam kerja yang biasa dan memforsir tenaga mereka lebih keras karena mereka bekerja tidak sesuai dengan porsinya.

Karena jumlah perusahaan industri yang cukup banyak inilah menimbulkan beberapa permasalahan bagi wanita yang sudah berkeluarga, mereka meninggalkan anak dalam waktu yang relatif lama, mengerjakan pekerjaan rumah dan harus berangkat pagi dengan waktu pulang yang relatif sudah sore. Kondisi capek dan stess kadang mewarnai kehidupan dalam keluarga.

Pekerjaan seperti di atas tidak semuanya berlaku bagi ibu rumah tangga khususnya yang sudah menikah dan memiliki anak, dan tidak bisa meninggalkan anak terlalu lama. Jam kerja dari jam 7 pagi sampai jam 5 sore dianggap menyita waktu mereka bersama dengan keluarganya, karena kondisi ini merupakan menyebabkan mereka kurang memberikan perhatian kepada anak-anaknya. Hal ini berdampak buruk bagi proses sosialisasi anak di masyarakat dan teman sebayanya. Anak-anak yang sedang mengalami proses pendewasaan sangat membutuhkan perhatian dan kasih sayang dari orang tuanya, namun orang tua yang sibuk bekerja membuat mereka merasakan kurang kasih sayang dan pada akhirnya mereka menghabiskan waktunya hanya bersama teman-temannya.

Disini anak berpikiran bahwa orangtua mereka tidak mempedulikannya dan hanya sibuk mencari uang, sehingga ia juga akan berperilaku sesuai keinginannya sendiri tanpa mempedulikan orang lain disekitarnya yang tidak nyaman atas tingkah laku mereka.

Meskipun kabupaten Kendal merupakan daerah yang luas lahan persawahannnya, namun masyarakat yang tidak punya keahlian khusus memilih bekerja di Semarang sebagai karyawan pabrik. Kota Semarang merupakan kota metropolitan terbesar kelima di Indonesia. Sebagai salah 
satu kota paling berkembang di Pulau Jawa, kota Semarang memiliki beberapa kawasan industri, yaitu kawasan industri di daerah Tugu, kawasan industri di Pelabuhan Tanjungmas, kawasan industri di daerah Terboyo, serta terdapat juga kawasan industri di sekitar daerah Ungaran.

Namun melihat kendala waktu yang harus dikorbankan meninggalkan keluarga, maka ada juga yang memilih bekerja paruh waktu di sekitar lingkungan rumah, misalnya memjadi buruh cuci, babysitter paroh waktu atau menjadi pembantu rumah tangga tetangga, atau hanya tinggal dirumah menghabiskan waktu dengan menjadi ibu rumah tangga sejati.

Saat ini di desa Jambearum Kabupaten Kendal berdiri sebuah usaha kerja industri kecil- kecilan. Bermula dari ide seorang karyawan yang di PHK dari perusahaan Kayu Lapis Indonesia, dia memberikan saran kepada seorang pemuda yang dianggap punya modal untuk membuat perusahaan kecil-kecilan yang barang produksinya bisa disetorkan ke pabrik Kayu Lapis Indonesia yang berada di Desa Ngebum kecamatan Kaliwungu Kabupaten Kendal.

Produksinya adalah pengeliman kayu sengon yang di potong sangat tipis yang ditata sedemikian rupa sehingga menjadi rekat setebal $4 \mathrm{~mm}$. pembuatannya sesuai dengan kebutuhan pabrik induk sehingga pembuatannya tidak asal jadi. Peminatnya cukup banyak, terbukti ada 10 orang ibu-ibu yang bekerja di tempat tersebut dengan upah yang lumayan menggembirakan. Upah tersebut dianggap sepadan dengan hasil jerih payah yang mereka lakukan. Mereka tidak meninggalkan keluarga, masih bisa mengerjakan pekerjaan rumah, bisa melihat anaknya bermain, bisa istirahat dan shalat dengan tenang karena tidak diburu waktu. Yang menyenangkan lagi adalah mereka bisa libur hari minggu disamping boleh ijin untuk melakukan aktifitas kemasyarakatan, seperti pengajian, perkumpulan dan lainnya karena di desa Jambearum sarat dengan majlis ta'lim dan pengajian ibuibu.

Waktu kerja relatif tidak berbeda dengan yang bekerja di kawasan industri Semarang yaitu antara jam 7.30 sampai jam 5, bedanya ibu-ibu yang bekerja di usaha kecil di dekat rumahnya, mereka tidak perlu terburuburu berangkat satu jam sebelum jam 7.30 karena lokasi di dekat rumah dan 
pulang tidak lebih dari jam 5.05, sementara yang bekerja dikawasan industri mungkin jam 6 baru bisa sampai dirumah. Ibu-ibu yang bekerja di dekat rumah masih bisa mengawasi anak dan merasa tenang karena tidak jauh dari rumah, sementara ibu-ibu yang bekerja di kawasan industri pikirannya tidak vokus karena selalu berpikir apakah anaknya sudah makan, sudah berangkat sekolah, tidak bolos sekolah, pulang dengan selamat dan masih banyak pikiran yang lainnya. Solusi yang diambil adalah mencari orang untuk menjaga anaknya sementara dia bekerja, lalu pertanyaannya apakah seimbang antara upah, waktu yang tersita dan perhatian anak, jika ternyata upahnya bekerja masih harus dibagi dengan orang yang menjaga anaknya. mungkin ini harus disorot dengan beban ganda yang harus dipikul wanita.

Lalu pertanyaan yang lain bagaimana jika ibu-ibu punya pikiran cerdas dengan mengambil pekerjaan paroh waktu disekitar rumahnya, atau bekerja di home industry sekitar tempat tinggalnya. Ternyata mata mereka berbinar bahagia dengan menerima gaji bekerjanya selama setengah bulan rata-rata Rp. 600.000. Mereka bisa mengerjakan pekerjaan rumah, mengurus anak dan keluarga serta mempunyai income sendiri. Dimana letak gender yang diperbincangkan. Mungkin mereka tidak terkena hukum feminism, gender, tidak merasa melakukan beban dan peran ganda atau justru mereka tidak tahu apa istilah gender, feminisme dan beban ganda. Yang ada dalam benak mereka adalah bahagia bisa membantu kebutuhan keluarga.

Saat ini sudah berdiri lagi usaha industri yang bergerak di bidang yang sama yang menyerap tenaga wanita juga dengan sistem kerja yang fleksibel, masih dengan waktu yang tidak terburu-buru, melihat pergaulan anaknya dan yang menyenangkan boleh ijin untuk acara pengajian ke majlis taklim.

Jika setiap daerah punya punya kearifan lokal sendiri, mungkin tidak ada wanita atau ibu rumah tangga yang tidak punya keahlian khusus, harus pergi jauh-jauh untuk menutup kekurangan keluarganya. Ini pekerjaan rumah yang tidak mudah agar wanita tetap terjaga harkat dan martabatnya tapi juga bahagia karena mampu ber-hasil guna untuk keluarganya.

\section{Simpulan}

Kita tidak bisa menutup mata bahwa wanita merupakan makhluq ciptaan Allah SWT yang luar biasa, tidak mudah mengeluh, putus asa dan 
gigih dalam berjuang, meskipun ada kasus-kasus tertentu yang berwujud sebaliknya. Haknya perlu di perhatikan bukan saja oleh para wanita yang mengetahui apa itu gender dan apa itu feminism. Namun laki-laki, ayah, suami, harus mau dan mampu meletakkan wanita pada tempatnya. Persoalan yang timbul bagaimana jika wanita itu bahagia ketika berada pada posisinya dimanapun dia berada dan bagaimanapun keadaannya, hanya hati kita yang bisa menjawab.[]

\section{Daftar Pustaka}

Ahmad, Syamsiah, "Kajian terhadap Masalah-masalah Wanita", Makalah, Jakarta:UI, 1990.

Echols, John, Hasan Shadzily, Kamus Inggris Indonesia, Jakarta: Gramedia Pustaka Utama, 1993.

Ensiklopedi Hukum Islam, Jakarta: Ikhtiar Baru van Hoeve, 1997.

Fakih, Mansour, Analisis Gender dan Transformasi Sosial, Yogyakarta: Pustaka Pelajar, 2001.

Faqih, Mansour Menggeser Konsepsi Gender dan Transformasi Sosial, Yogyakarta: Pustaka Pelajar, 1996.

Mas'udi, Masdar F, Islam dan Hak hak Reproduksi Perempuan Dialog Fiqih Pemberdayaan, Bandung, Mizan 2000.

Mosse, Julia Cleves, Gender dan Pembangunan, terj: Hartian Silawatim, Yogyakarta: Pustaka Pelajar, 2002,

Munawwar, Khalil, Nilai Wanita, cet. VIII, Solo: Ramadani, 1987.

Purwadi dkk., Ensiklopedi Kebudayaan Jawa, Yogyakarta: Bina Media, 2005.

Shahih Bukhari, t.th.

Shahih Muslim, t.th.

Shihab, Quraish, Membumikan al Qur'an, Peran dan Fungsi Wahyu dalam Kehidupan Masyarakat, Bandung: Mizan, 1994.

Suwondo, Nani, Kedudukan wanita Idonesia dalam Hukum dan Masyarakat, Jakarta: Ghalia Indonesia, 1981. 
Tilaar, Marta, Citra Indonesia Tahun 2000, Kemandirian dalam menjawab Tantangan Pembangunan Tan, Melly G, Perempuan Indonesia Pemimpin Masa depan?, Jakarta: Pustaka Sinar Harapan, 1991.

Zaitunah, Subhan, Tafsir Kebencian, Bias Studi Gender dalam Tafsir Qur'an, Yogyakarta, LKiS, 1999. 
